\title{
Another Interview With Jon Lindsey
}

A year ago you became editor of North Carolina Libraries. What has happened with the publication during this year?

During 1979 North Carolina Libraries has published the final issue of volume 36 , four issues of volume 37 , indexes for volumes $34-36$, and a directory of individual members. In addition, on recommendation of the Board of North Carolina Libraries the NCLA Executive Board approved underwriting the costs to provide Tar Heel Libraries as a benefit of membership in NCLA. Since June all personal members of NCLA have received Tar Heel Libraries.

What is the significance of this amount of production?

This has provided the membership of NCLA with a journal on a regular bases, and the provision of Tar Heel Libraries is an attempt to maintain currency through the calendar which is published in it. Through cooperation between the two publications we feel that NCLA members are kept Current on a variety of subjects. Also, at this point, the editorial board of $\mathrm{NCL}$ can concentrate on developing articles from the ten sections of NCLA which speak to the interests and needs of the association.

What are the weak areas of NCL? Published elsewhere in this issue (page 53) is a report of the reader survey
of NCL which was done at the biennial meeting at Charlotte. Some of the duringses of the journal are evident there, and the board will be working the coming year to strengthen these areas.

You

Si

to have skirted the question

to published librarians. I am not sure that the articles which have been NCL A. in the past year have had a lot of appeal for this large group in will have are making some efforts to correcit this in the next issue which the Fall a special feature on literature for children and young adults. In librarians will emphasize bibliographic instruction. I hope that school instruction will provide information about how they are doing bibliographic Another, and with what success.

Sraphical weakness of the past year could be seen in terms of the geopublished. we are limited hope to maintain a balance on this, but at the same time profession. 
Q. What kinds of articles are you looking for?

A. Articles which speak to the professional interests of librarians, and wit. speak to the specific concerns of librarians.

Q. That sounds nice, but can you be more specific?

A. To be more specific is difficult, but there are some issues in North Caro which need to be addressed by librarians. For instance, Bill O'S recently spoke to the issue of cooperation. In this issue of NCL we speaking to the question of professional preparation for functioning librarian, and have included an article by Louise Boone about the ce cation of public librarians in North Carolina. In a future issue of the joul we hope to look at the dynamics of community school libraries and public and school library administrations may deal with this legisla reality.

The mail ballot to the membership of NCLA (see results on page raises a primary issue which librarians must face. This is not the ques of the Equal Rights Amendment, but it is really the question of to " degree or even shall the association become an advocate of a so political issue. Openly becoming an advocate appears to some librar to violate their traditional image as objective, nonjudgmental disse nators of information. Other issues which affect the future of libran throughout the state are those connected with formulas for federal state funds, unionization either through direct unions or obliquely thro! organizations like the North Carolina Association of Educators, and implications of a National Libraries Act.

Q. Well, you did manage to be more specific. Are there any other is which quickly come to mind?

A. An issue which confronts the North Carolina Library Association is question of whether it is meeting the needs of its membership. The as ciation may need to face the question of its structure/organization whether this meets or speaks to the needs of librarians in the state. As largest state library association in the Southeast, North Carolina ha responsibility to maintain a high level of leadership.

Q. What is the role that North Carolina Libraries should play in facing thi issues?

A. First, the journal plays a role by calling attention to the issues. Second plays a role as the membership of the association is willing to take the t to use the journal as a forum for the discussion of the issues. Third, journal plays a role as a regional and national voice.

In addition to being a focus for facing issues of librarianship, the jout has an important role to play in being responsible to its constituency communicating to members of the North Carolina Library Association decisions of the NCLA Executive Board and the activities of committ and sections. 
How should the membership of NCLA assume its responsibility?

One avenue is to take the time to write so that colleagues can be made aware of the various positions available on any one issue. Another avenue is to involve oneself in the activities of the sections of the association.

A third avenue is to respond critically to items which appear in the journal. A final avenue is to be directly aware of the section editors and to respond to them with ideas, articles, information, and evaluations of the journal's response to membership needs. We have an excellent editorial board and a group of individuals who are responsive to their sections and section interests.

Jonathan A. Lindsey, editor

Now Antiquarian Booksellers and Librarians Can Quickly

Scan Hundreds of Antiquarian Dealers' Updated Catalogs and Lists on Easy-to-Handle Microfiche

\section{ANTIQUARIAN TRADE LIST ANNUAL (ATLA) 1980}

The very first Antiquarian Trade List Annual published on space-saving microfiche gives you ...

- The Latest Antiquarian Information at

Your Fingertips

Finding Titject Index That Makes

- Rare, ()/P, \& Used Beoks Information

- Prints, Maps, \& Autographs Information

- Catalogs and Lists from 1)omestic and Foreign Antiquarians

For further information on ATLA, write for a free brochure.

Subscription Prices

ATLA 1980

ATLA 1980 with Kodak Microfiche Reader

All Supplements for 1980

(New \& Updated Information)

$\begin{array}{ccccc}\frac{\text { US \& Canada }}{\$ 150.00} & & \text { Other Countries } & \begin{array}{c}\text { Other Countries } \\ \text { (Airmail) }\end{array} \\ \$ 160.00 & & \$ 170.00 \\ \$ 240.00 & & \$ 275.00 & & \$ 305.00 \\ \$ 50.00 & & \$ 55.00 & & \$ 60.00\end{array}$




\section{The dollars and sense of buyi books instead of leasing then}

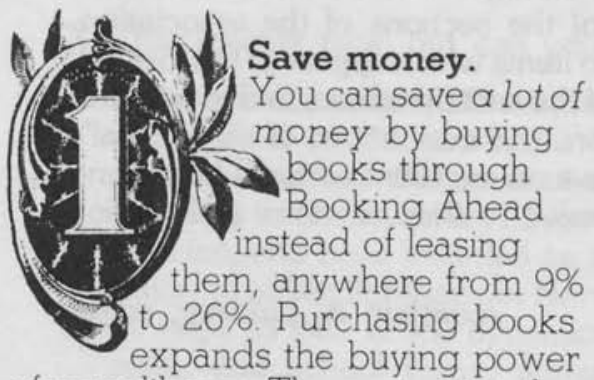

of your library. The coupon at the bottom of this page will bring you some very impressive cost comparisons, plus a lot more information.

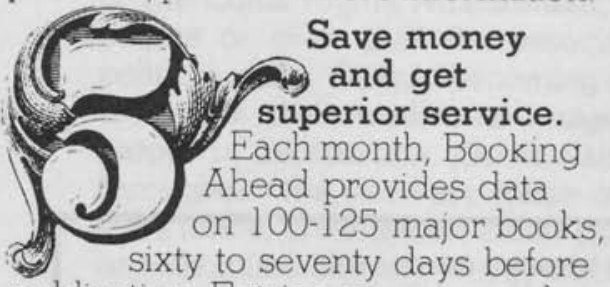
publication. Entries are arranged within categories: General Fiction, Adventure/Suspense, Historical Novels, Mystery, Romance, Science Fiction and Non-Fiction. Booking Ahead allows you to order the specific titles you want in the quantities you need. Or, if you prefer, we can enroll you in an automatic shipment plan

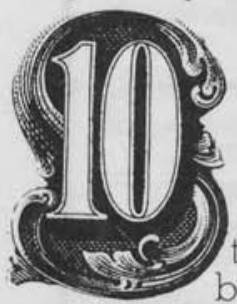

Save money and get complete selection data. Each Booking Ähead title is fully annotated to help you select those new titles that best suit your patrons needs. Complete bibliographic information is also furnished.

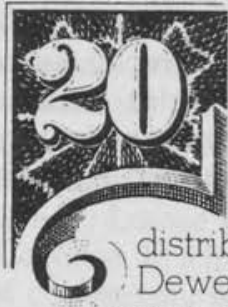

Save money and shelf ready boo: All titles listed in Booking Ahead al available from eac Baker \& Taylor

processing is available you prefer, partial processing

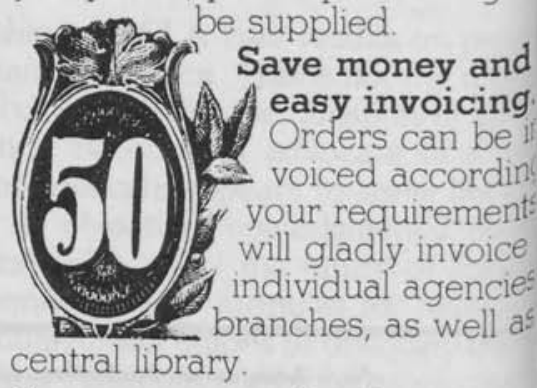

Save money and get Booking Ahead.

Booking Ahead is Baker \& Taylo alternative to leasing programs. It allows you to get popular read titles in the quantities you need when you need them - econom

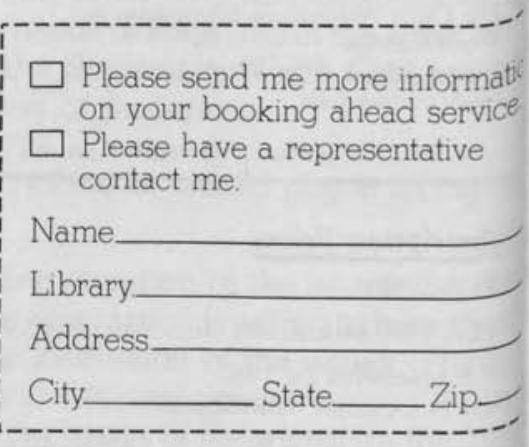

\section{The Baker \& Taylor Company The Librarian's}

Eastern Division 50 Kirby Avenue, Somerville. New Jersey 08876 Tel 201-722-8000 Southern Division Commerce, Georgia 30529 Tel 404-335-5000

Midwestern Division Gladiola Avenue, Momence, Illinois 60954 Tel: 815-472-2444

Western Division 380 Edison Way, Reno, Nevada 89564 Tel: 702-786-6700 